\title{
DDA1 Gene
}

National Cancer Institute

\section{Source}

National Cancer Institute. DDA1 Gene. NCI Thesaurus. Code C119625.

This gene may be involved in protein ubiquitination and turnover. 